\title{
Experimental Evaluation on Performance of Open Kitchen Fire Suppression Systems
}

\author{
W.K. CHOW ${ }^{1}$, and XIAOMIN NI ${ }^{1,2}$ \\ ${ }^{1}$ Research Centre for Fire Engineering, Department of Building Services Engineering, \\ The Hong Kong Polytechnic University, Hong Kong, China \\ ${ }^{2}$ State Key Laboratory of Fire Science, University of Science and Technology of China, Hefei, \\ Anhui, China
}

\begin{abstract}
Experiments with burning cooking oil in open kitchen fires are reported in this paper. Heat release rate, flame temperature, burning duration and heat fluxes of cooking oil fires were measured. Performances of water mist and gas-solid composite dry powders in suppressing cooking oil fires were evaluated by experiments. Reduction in gas temperature distributions, changes in heat fluxes and suppression time were then measured. Experimental data will provide necessary information for hazard assessment of open kitchen in the residential units of tall buildings.
\end{abstract}

KEYWORDS: open kitchen, suppression, heat release rate.

\section{INTRODUCTION}

In Southeast Asia, including Hong Kong, many small units which area is less than $30 \mathrm{~m}^{2}$ in tall residential buildings over $200 \mathrm{~m}$ contain open kitchens [1,2]. Fire safety provisions are determined by performancebased design [1,3-5], but it is not supported by full-scale burning tests. It is specified that open flame cooking equipment such as gas cookers are not allowed. Additional fire protection systems, such as water mist suppression or dry powder systems, have to be installed [1,6,7] above the kitchen stoves. However, kitchen fire hazards with and without fire-resistant walls were not studied thoroughly. Fire risks arise due to cooking in a kitchen [8-12]. A recent experimental study reported that a fire can be started within ten minutes, when a person fries food with cooking oil using the permitted electric induction cookers [13]. In a normal enclosed kitchen fire, the maximum fire size is limited by the air supply rate through the openings. But the same cooking oil fire would grow rapidly due to an adequate air supply in an open kitchen, which is not enclosed by fire-resistant walls.

Three conditions are imposed [1] by the Authorities. Firstly, gas cookers cannot be used, and only flameless electric induction cookers are allowed. Secondly, additional fire suppression systems, including water mist [14] or dry powder [15] systems, are specified for installation. The systems are supposed to stop the stove fire and prevent it from growing. The flat owner cannot remove the system or change the stove without approval from the government. Thirdly, the estate management office has to sign an undertaking agreement to implement the approved fire safety management procedures [4,5] specified in the performance-based design report.

It is expected that the specified active fire suppression systems utilizing water mist [14] or dry powder [15] can suppress a cooking fire [16] in open kitchens in the early stage. However, their performance was only evaluated under small stove fire. Further, the suppressing agent was discharged almost immediate upon ignition of food in the pan. In this paper, the performance of the installed fire systems in bigger fires was evaluated in a series of experiments. Experimental data indicated how the installed systems perform in an open kitchen fire [17]. Improvements through the use of new gas-solid composite particles developed recently [18] were evaluated. Appropriate system designs [7] for high-level fire hazards can then be recommended to prevent kitchen fire growth.

Performances of the recommended water mist and dry powder systems [14,15] were evaluated in experiments under a bigger stove fire. Systems complying with the specification were installed in the room calorimeter. Three open kitchen scenarios were studied in an experimental chamber which has a similar size to a room calorimeter. In the first scenario, cooking oil was burnt in a wok (Chinese cooking pan); in the second scenario, a water mist system was operating [14]; a dry powder system was running in the third scenario [15]. The key fire parameters, including burning duration, peak heat release rates and maximum heat flux, were deduced. The effects of water sprays and dry powder on the burning stove fires were studied from the measured air temperatures, heat fluxes and heat release rates in a similar manner to other 
works [9,19-21]. Reductions in peak heat release rates and maximum heat flux while the suppression system was operating were assessed.

\section{EXPERIMENTAL STUDIES}

Experiments on kitchen cooking fires were conducted in a room of length $5.2 \mathrm{~m}$, width $4.5 \mathrm{~m}$ and height $3.6 \mathrm{~m}$. A $2.4 \mathrm{~m} \mathrm{x} 2.4 \mathrm{~m} \times 1 \mathrm{~m}$ exhaust hood was constructed above the wok and connected to a fan-duct system. Smoke was collected to measure heat release rate (HRR) by analyzing oxygen concentration $\left[\mathrm{O}_{2}\right]$, carbon dioxide concentration $\left[\mathrm{CO}_{2}\right]$ and carbon monoxide concentration [CO]; the data was recorded at $5 \mathrm{~s}$ intervals. Deviation of the measured HRR values was within $5 \%$.

A schematic diagram of the experimental setup is shown in Fig. 1. A new stainless wok with diameter 25 $\mathrm{cm}$ and depth $5 \mathrm{~cm}$ was placed on a table at a height of $80 \mathrm{~cm}$. The cooking oil used was vegetable cooking oil blended with canola, soybean and peanut oils. In each test, $500 \mathrm{ml}$ oil was poured into the wok and the ullage was about $80 \%$ of the wok. The process of each test was recorded by a video with the rate of 24 frames per second.

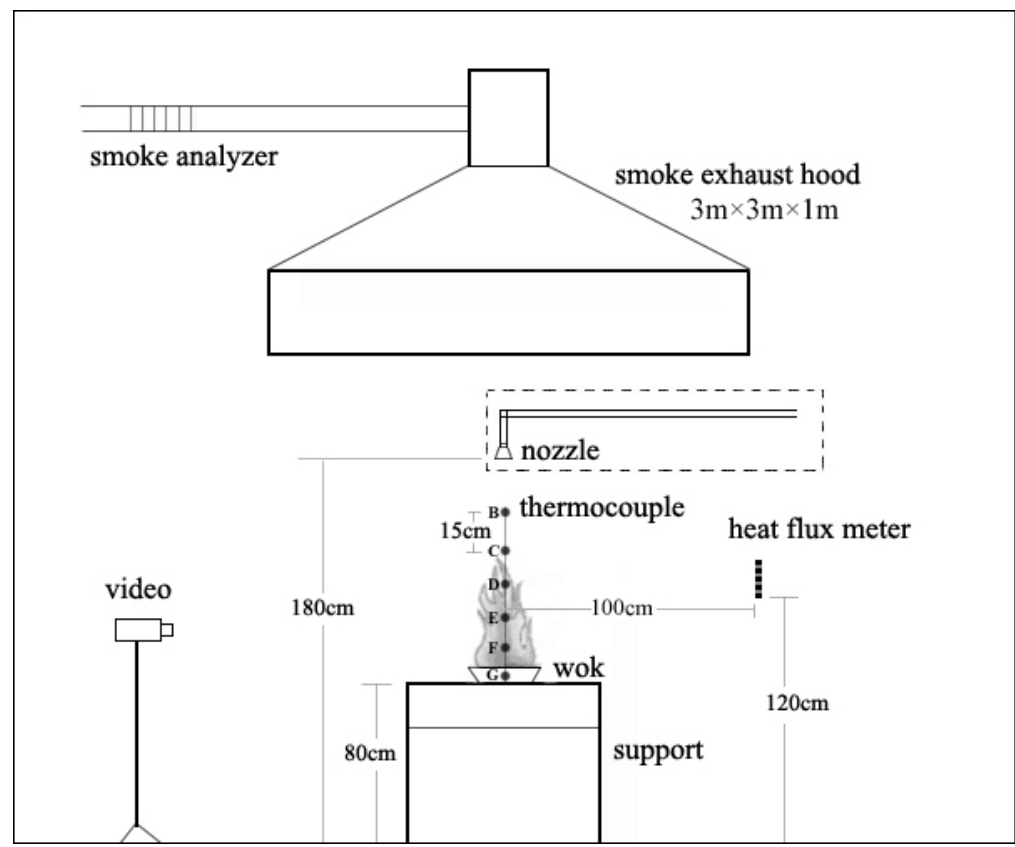

Fig. 1. Schematic illustration of experimental setup.

A thermocouple tree with six thermocouples was set up. One thermocouple was placed below the oil surface to measure the oil temperature. The remainders were set above the oil surface at $15 \mathrm{~cm}$ intervals to measure air temperatures. The thermocouples were K-type sheathed and grounded with a diameter of $1 \mathrm{~mm}$. The detected temperature range of TCs was -40 to $1200^{\circ} \mathrm{C}$ with a response time of $0.5 \mathrm{~s}$.

Radiative heat flux of the flame was recorded by a heat flux meter (Captec, TS-30) with the size of $30 \mathrm{~mm}$ $\times 30 \mathrm{~mm} \times 0.4 \mathrm{~mm}$. The measuring range is $\pm 200 \mathrm{~kW} / \mathrm{m}^{2}$ with an accuracy of $\pm 3 \%$. The heat flux meter was placed near to the flame with a perpendicular distance to the floor of $1.2 \mathrm{~m}$ and the horizontal distance to the wok center of $1.0 \mathrm{~m}$. Before testing, the heat flux meter was calibrated with a standard newly bought one.

For fire suppression tests with water mist, plain water was put in a $3.0 \mathrm{~L}$ container without using any additives such as surfactants, inorganic and organic salts. The nozzle was set vertically above the pan at a $1.0 \mathrm{~m}$ distance. In each test, $2.5 \mathrm{~L}$ liquid agent was added into the container and pressurized by nitrogen to the assigned gauge pressure. The nozzle contains four orifices of k-factor of 3.5 (flow rate Q in $1 / \mathrm{min}$, operating pressure $\mathrm{P}$ in $\mathrm{MPa}$ ). Sauter mean diameter (SMD) of the droplets at the location of the wok was measured by shadowgraphy method with Lavision laser diagnostic techniques. 
In the powder suppression tests, gas-solid composite powders were used, which were composed of zeolite 13x particles soaked with 2-bromo-3,3,3-trifluoropropene. The average diameter of the composite particles was $1.8 \mu \mathrm{m}$ by scanning electron microscopy (SEM) observation. The powder container had an internal diameter of $63.5 \mathrm{~mm}$ and a height of $100 \mathrm{~mm}$. The brass cone-shaped nozzle had an internal diameter of 2.2 $\mathrm{mm}$ and a cone angle of $60^{\circ}$. The nozzle was set vertically above the pan $1.0 \mathrm{~m}$ away. In each test, $100 \mathrm{~g}$ powders were added into the container and pressurized by nitrogen to a pre-assigned value. The valve was turned off as soon as the fire was extinguished.

\section{COOKING OIL FIRES}

Cooking oil was difficult to ignite because of its high flashpoint. An electric stove was used to heat the cooking oil to autoignition. Then, the electric stove was removed to let the cooking oil burning freely. The type of electric stove may affect the heating process, hence different ignition time of cooking oil was recorded. As the objective of this study is to measure the parameters of the cooking oil fires, such heating up process would have minimum effect.

Three burning tests B-1, B-2 and B-3 were carried out [details were listed in Table 1]. The thermal power of the electric stove was $3 \mathrm{~kW}$. Ambient air temperature was $20^{\circ} \mathrm{C}$ and relative humidity was $50 \%$.

Table 1. Experimental conditions of the burning tests.

\begin{tabular}{|c|c|c|c|c|}
\hline \multicolumn{2}{|l|}{ Test Number } & B-1 & B-2 & B-3 \\
\hline \multicolumn{2}{|l|}{ Volume of oil added (ml) } & 450 & 500 & 500 \\
\hline \multicolumn{2}{|l|}{ Ignition time (s) } & 1544 & 1728 & 1767 \\
\hline \multicolumn{2}{|l|}{ Burning duration (s) } & 446 & 514 & 519 \\
\hline \multicolumn{2}{|c|}{ Average mass loss rate $(\mathrm{g} / \mathrm{s})$} & 1.08 & 1.06 & 1.05 \\
\hline \multicolumn{2}{|c|}{ Mass loss rate per area $\left(\mathrm{kg} / \mathrm{m}^{2} \cdot \mathrm{s}\right)$} & 0.0220 & 0.0216 & 0.0214 \\
\hline \multicolumn{2}{|c|}{ Measured maximum HRR $(\mathrm{kW})$} & 33.0 & 33.2 & 29.9 \\
\hline \multicolumn{2}{|c|}{ Measured average HRR $(\mathrm{kW})$} & 26.8 & 25.3 & 24.7 \\
\hline \multicolumn{2}{|c|}{ Combustion efficiency factor $(\Phi)$} & 0.66 & 0.63 & 0.62 \\
\hline \multicolumn{2}{|c|}{ Temperature measured at ignition $\left({ }^{\circ} \mathrm{C}\right)$} & 406.4 & 378.2 & 376.5 \\
\hline \multicolumn{2}{|c|}{ Peak flame temperature $\left({ }^{\circ} \mathrm{C}\right)$} & 675.2 & 640.8 & 681.1 \\
\hline \multicolumn{2}{|l|}{ Radiative heat flux $\left(\mathrm{kW} / \mathrm{m}^{2}\right)$} & 0.109 & 0.113 & 0.115 \\
\hline \multirow{3}{*}{ Smoke composition $(\mathrm{v} \%)$} & $\operatorname{Max}[\mathrm{CO}]$ & $1.76 \times 10^{-3}$ & $2.00 \times 10^{-3}$ & $2.34 \times 10^{-3}$ \\
\hline & $\operatorname{Max}\left[\mathrm{CO}_{2}\right]$ & $9.26 \times 10^{-2}$ & $9.75 \times 10^{-2}$ & $9.64 \times 10^{-2}$ \\
\hline & $\operatorname{Min}\left[\mathrm{O}_{2}\right]$ & 20.8641 & 20.8637 & 20.8723 \\
\hline
\end{tabular}

Variations of the mass of cooking oil which are recorded at different times are shown in Fig. 2. The average mass loss rates of the cooking oil while burning were estimated to be $1.08 \mathrm{~g} / \mathrm{s}, 1.06 \mathrm{~g} / \mathrm{s}$ and $1.05 \mathrm{~g} / \mathrm{s}$ respectively. In test B-1, the initial volume of cooking oil was smaller. The burning rate became higher.

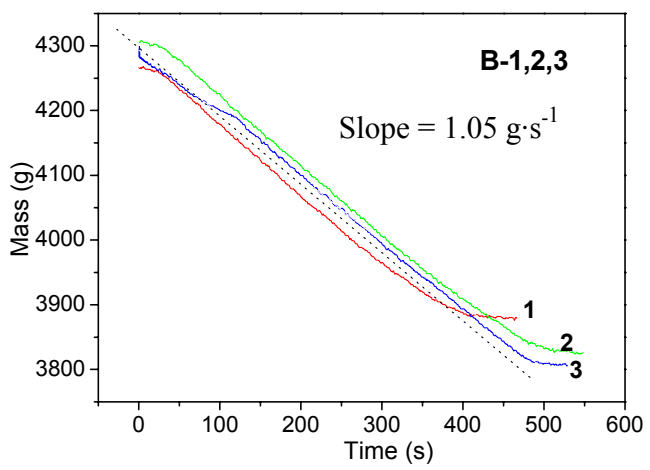

Fig. 2. Mass loss rate of the three burning tests. 
It was found that the measured mass loss rate was higher than that of the literature value of $0.0043 \mathrm{~kg} / \mathrm{m}^{2} \cdot \mathrm{s}$, reported with much smaller burning pan of diameter $9 \mathrm{~cm} \mathrm{[22].} \mathrm{Different} \mathrm{experimental} \mathrm{conditions} \mathrm{would}$ affect the burning rate. Also, the cooking oil used might be different.

In the experiments, heat release rate was measured by oxygen consumption calorimetry (e.g. ASTM E1354) [23]. In this method, a constant heat of $13100 \mathrm{~kJ} / \mathrm{kg}$ oxygen was consumed with accuracy $\pm 5 \%$ with burning most hydrocarbon fuels. After ignition, all of the combustion products were collected in the hood, as shown in Fig. 1. The gases would go through an exhaust duct where the flow rate and composition of the gases was measured. Using empirical equations, the HRR can then be computed [24,25].

HRR curves for the three tests are plotted in Fig. 3. Similar varying patterns of time and peak HRR were spotted; the peak HRR was approximately $33 \mathrm{~kW}$ in the three tests. The accuracy is within $\pm 5 \%$.

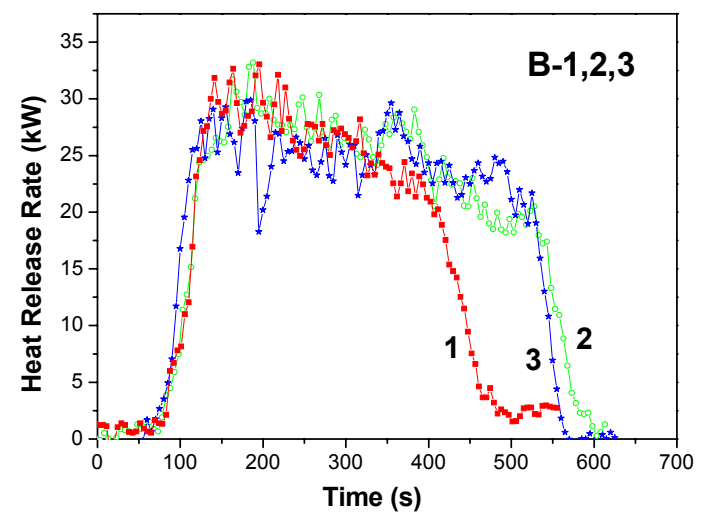

Fig. 3. Heat release rate for tests B-1 to B-3.

From the mass loss rate of the three burning tests shown in Table 2, the combustion efficiency factor $\Phi$ of the cooking oil could be estimated by the formula, using the above measured HRR, the mass loss rate $\dot{m}$ and the effective heat of combustion $\Delta H_{c, \text { eff }}$ (in $\mathrm{kJ} / \mathrm{kg}$ ):

$Q=\Phi \times \dot{m} \times \Delta H_{c, e f f}$

$\Delta H_{c, \text { eff }}$ is $42000 \mathrm{~kJ}$, and the values of $\dot{m}$ are $1.08 \mathrm{~g} / \mathrm{s}, 1.06 \mathrm{~g} / \mathrm{s}$ and $1.05 \mathrm{~g} / \mathrm{s}$ for the three tests respectively. Then, the values of $\Phi$ could be estimated as $0.658,0.632$ and 0.624 by the formula.

The values measured in the experiments were much lower than the reported data in other publications $[11,12]$. As shown in Appendix A [11], the maximum HRR of corn oil in a pot with a 10 inch $(\sim 25.4 \mathrm{~cm})$ diameter was about $400 \mathrm{~kW}$, much higher than the values measured in our tests using a similar size. The significantly different HRR values were ascribed to the different situations in the two cases. The present testing regime involved freely burning wok fire, as opposed to a stove fire with the heat input to the fuel both from the fire itself and from the heating element of the stove in reference [11]. According to the Blinov and Khudyakov diagram of the regression rates from pool fires [26], the regression rate of pool fires (except in the conduction-dominated regime) is generally limited to about $4 \mathrm{~mm} / \mathrm{min}$. Thus, the yielding maximum HRR for the present situation of about $120 \mathrm{~kW}$. The number of $400 \mathrm{~kW}$ quoted on the basis of reference [11] is not possible in the absence of external heating of the fuel.

The temperatures recorded by the thermocouple tree for the three tests are shown in Fig. 4 . The oil temperatures ranged from 380 to $406^{\circ} \mathrm{C}$. The peak flame temperatures were from $640^{\circ} \mathrm{C}$ to $681^{\circ} \mathrm{C}$. Thermocouple B (TC-B) was immersed in the cooking oil to record the oil temperature during burning. When the oil surface burnt to a position located below the thermocouple, TC-B would measure the flame temperature.

The radiative heat fluxes are shown in Fig. 5. The peak radiative heat flux was about $0.11 \mathrm{~kW} / \mathrm{m}^{2}$ at the detection position, as shown in Table 1. Fig. 6 gave the typical variation of concentrations of $\mathrm{O}_{2}, \mathrm{CO}_{2}$ and 
$\mathrm{CO}$ with time in test $\mathrm{B}-2$. The other two tests gave the similar curves. The maximum concentration of $\mathrm{CO}$, $\mathrm{CO}_{2}$ and minimum concentration of $\mathrm{O}_{2}$ detected during the three burning processes were given in Table 1.

Fig. 7 gave the typical photographs of test B-2. It was shown that the cooking oil fires have bright flames and produce large volume of smoke. The peak flame height was about $70 \mathrm{~cm}$, while the burning lasts for about $514 \mathrm{~s}$. For B-1 with less oil, the burning lasts for a shorter time. In the experiments, the air pumping effect for measuring HRR gave rise to 'jumping flames' and 'fire whirling' [27].

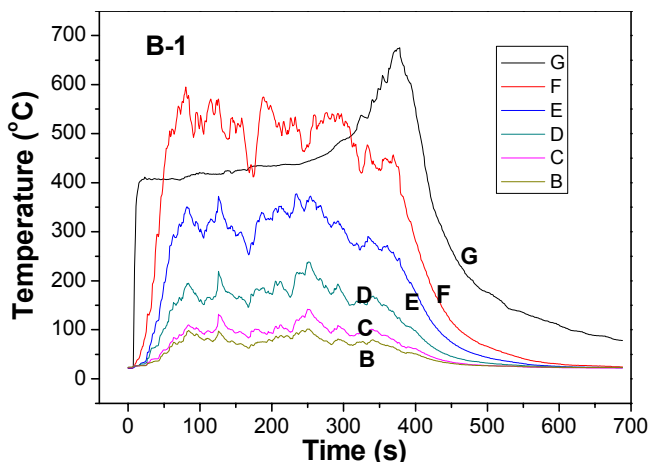

(a) Test B1

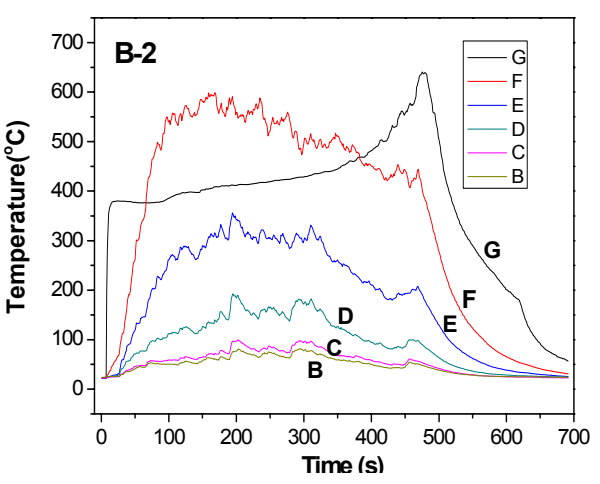

(b) Test B2

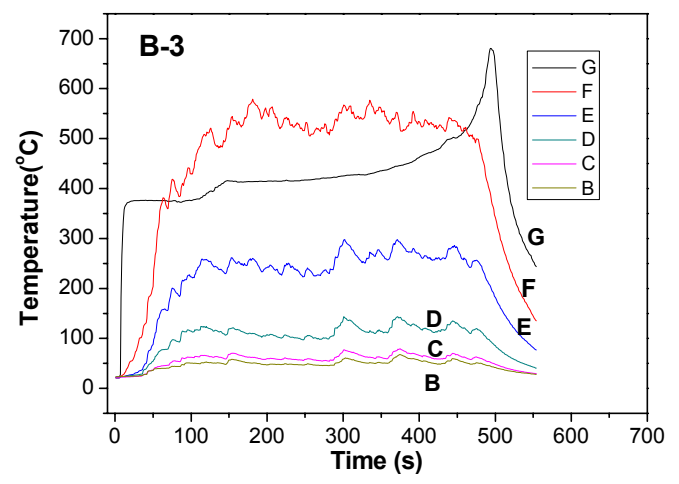

(c) Test B3

Fig. 4. Temperature curves for tests B-1 to B-3.

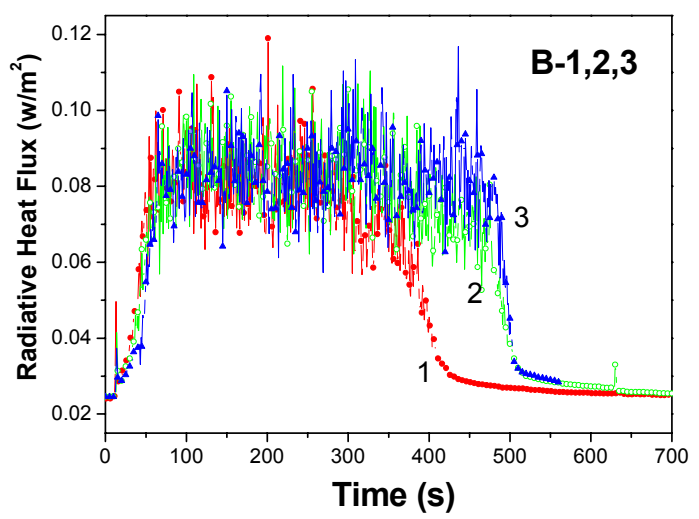

Fig. 5. Radiative heat fluxes for tests B-1 to B-3. 


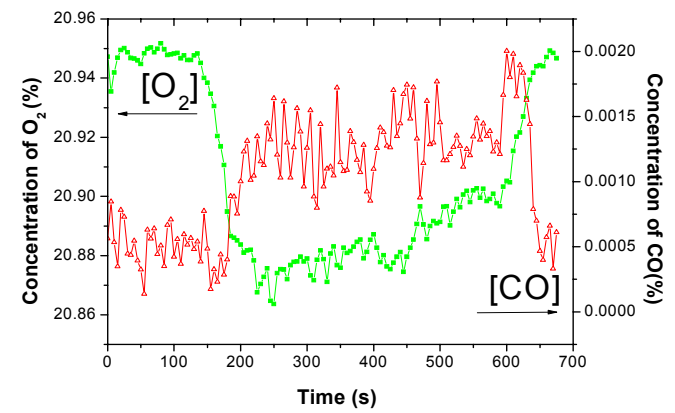

(a) Test B-2 $\left[\mathrm{O}_{2}\right]$ and $[\mathrm{CO}]$

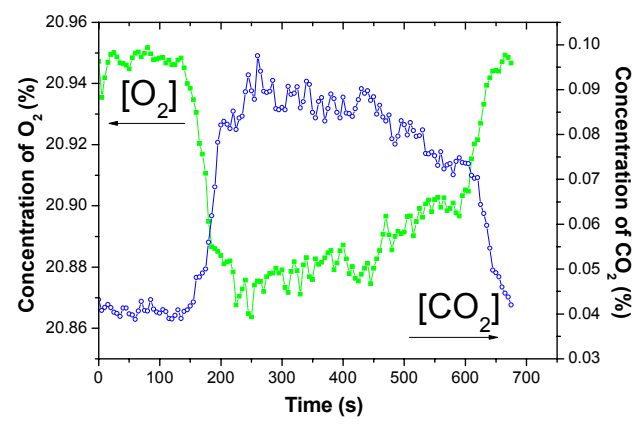

(b) Test B-2 $\left[\mathrm{O}_{2}\right]$ and $\left[\mathrm{CO}_{2}\right]$

Fig. 6. Gas concentrations in test B-2.

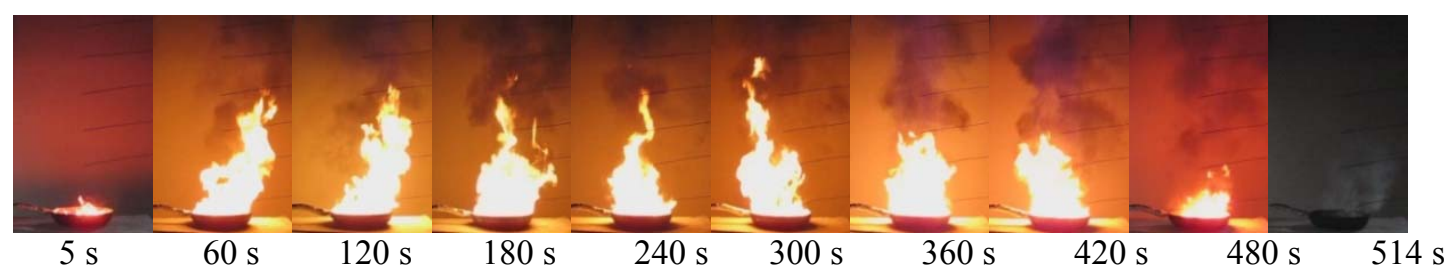

Fig. 7. Typical Photographs for test B-2

\section{SUPPRESSION WITH WATER MIST}

Three tests labeled as SWM-1 to SWM-4 were carried out, and their summary is shown in Table 2. In all tests, the initial volume of water was 2.5 litres. $500 \mathrm{ml}$ of cooking oil was poured in the wok in the tests. Ambient air temperature was $20^{\circ} \mathrm{C}$ with $50 \%$ relative humidity.

Table 2. Fire suppression tests with water mist.

\begin{tabular}{|c|c|c|c|c|c|}
\hline \multicolumn{2}{|l|}{ Test Number } & SWM-1 & SWM-2 & SWM-3 & SWM-4 \\
\hline \multicolumn{2}{|c|}{ Discharge pressure $(\mathrm{MPa})$} & 0.8 & 0.8 & 0.6 & 0.4 \\
\hline \multicolumn{2}{|c|}{ Height of nozzle (to floor) (m) } & 1.8 & 1.8 & 1.8 & 1.5 \\
\hline \multicolumn{2}{|c|}{ Sauter mean diameter of the droplets $(\mu \mathrm{m})$} & 216 & 209 & 232 & 254 \\
\hline \multicolumn{2}{|c|}{ Pre-burning time (s) } & 120 & 120 & 120 & 120 \\
\hline \multicolumn{2}{|c|}{ Peak HRR before water mist discharge $(\mathrm{kW})$} & 36.4 & 38.8 & 34.3 & 44.8 \\
\hline \multicolumn{2}{|c|}{ Peak HRR after water mist discharge $(\mathrm{kW})$} & 630.7 & 868.1 & 358.8 & 111.2 \\
\hline \multicolumn{2}{|c|}{ Peak cooking oil temperature $\left({ }^{\circ} \mathrm{C}\right)$} & 393.1 & 391.7 & 417.7 & 415.1 \\
\hline \multicolumn{2}{|c|}{ Peak flame temperature $\left({ }^{\circ} \mathrm{C}\right)$} & 446.2 & 462.8 & 463.8 & 721.8 \\
\hline \multicolumn{2}{|c|}{$\begin{array}{l}\text { Peak radiative heat flux }\left(\mathrm{kW} / \mathrm{m}^{2}\right) \text { before water } \\
\text { mist discharged }\end{array}$} & 0.127 & 0.187 & 0.134 & 0.119 \\
\hline \multicolumn{2}{|c|}{$\begin{array}{l}\text { Peak radiative heat flux }\left(\mathrm{kW} / \mathrm{m}^{2}\right) \text { after water mist } \\
\text { discharged }\end{array}$} & --- & --- & 1.15 & 0.263 \\
\hline \multicolumn{2}{|c|}{ Fire extinguishing time $t_{\mathrm{E}}(\mathrm{s})$} & 4.0 & 3.0 & 7.0 & $\begin{array}{c}\text { Not } \\
\text { extinguished }\end{array}$ \\
\hline \multicolumn{2}{|c|}{$\begin{array}{l}\text { Volume of water consumed for fire } \\
\text { extinguishment } V_{E}(L)\end{array}$} & 1.6 & 1.1 & 2.2 & 2.5 \\
\hline \multirow[t]{2}{*}{$\operatorname{Max}[\mathrm{CO}](\mathrm{v} \%)$} & Before & $1.65 \times 10^{-2}$ & $1.51 \times 10^{-2}$ & $1.96 \times 10^{-2}$ & $1.93 \times 10^{-2}$ \\
\hline & After & $2.33 \times 10^{-2}$ & $4.63 \times 10^{-2}$ & $1.41 \times 10^{-1}$ & $6.73 \times 10^{-3}$ \\
\hline \multirow{2}{*}{$\operatorname{Max}\left[\mathrm{CO}_{2}\right](\mathrm{v} \%)$} & Before & $8.96 \times 10^{-2}$ & $9.81 \times 10^{-2}$ & $9.90 \times 10^{-2}$ & $1.11 \times 10^{-1}$ \\
\hline & After & 1.19 & 2.14 & 0.993 & 0.212 \\
\hline \multirow{2}{*}{$\operatorname{Min}\left[\mathrm{O}_{2}\right](\mathrm{v} \%)$} & Before & 20.8555 & 20.8491 & 20.8609 & 20.8336 \\
\hline & After & 19.3103 & 18.6929 & 20.0171 & 20.6610 \\
\hline
\end{tabular}

---: The point was recognized as outlier for unknown reasons, so the peak value could not be given out. 
The heat release rates for the four tests are shown in Fig. 8 and air temperature in Fig. 9. Radiative heat fluxes are shown in Fig. 10, in which peak values of SWM-1 and SWM-2 are beyond the detection limit. Typical $\left[\mathrm{O}_{2}\right],\left[\mathrm{CO}_{2}\right]$ and $[\mathrm{CO}]$ curves of SWM-2 are shown in Fig. 11. The other three tests gave the similar curves to SWM-2. The peak concentrations of $\mathrm{CO}$ and $\mathrm{CO}_{2}$ before and after water mist discharged of each test were presented in Table 2. It was demonstrated that after water mist discharged, concentrations of $\mathrm{CO}$ and $\mathrm{CO}_{2}$ were greatly increased.

Upon discharging water mist, it was observed that the flame of the cooking oil was stronger in the suppression tests SMW-1 to SMW-3, as shown in Fig. 12. This observation is consistent with the literature results [28]. The flame enhancement generated a higher HRR and heat flux. Some oil was splashed out.

In SMW-4, the flame was not extinguished for the low pressure water mist with low momentum, and water mist might not pass the flame to reach the burning oil surface.

The maximum flame temperature of all the three tests should be above $700^{\circ} \mathrm{C}$ as reported in the literature [18]. Recorded temperatures for SMW-1 to SMW-3 were lower than $460^{\circ} \mathrm{C}$. A possible reason is that these thermocouples were not located within the flame area with higher temperature.

Although water mist performed well in suppressing cooking oil fires, safety concerns including flame enlargement and oil spill should also be taken into consideration.

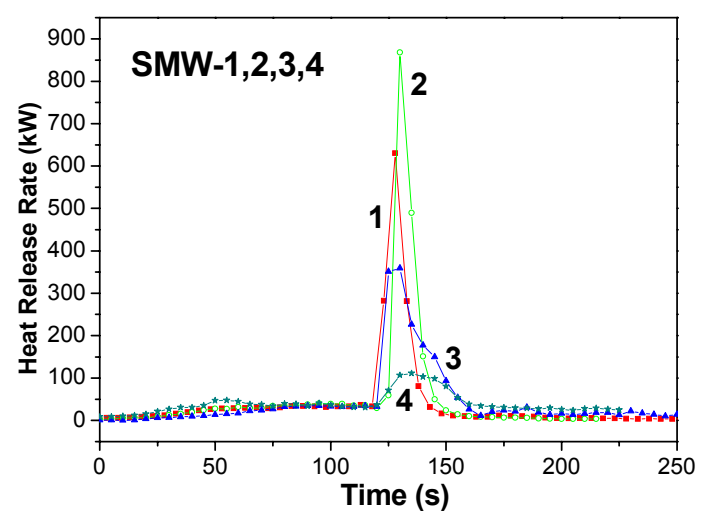

Fig. 8. Heat release rate measured for tests SMW-1 to SMW-4.

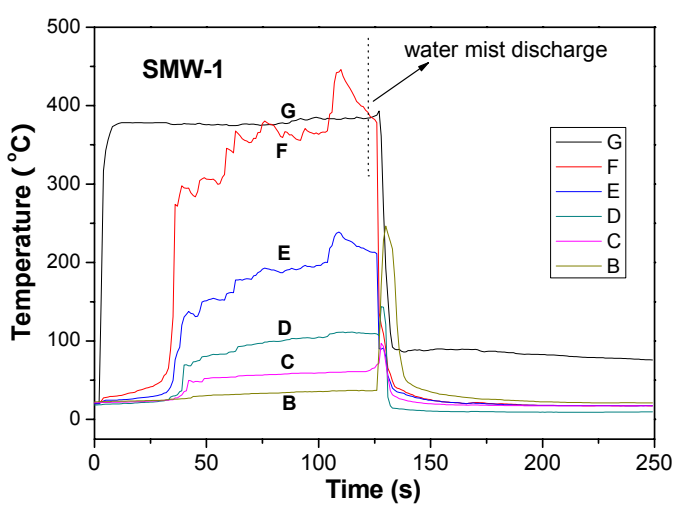

(a) Test SMW-1

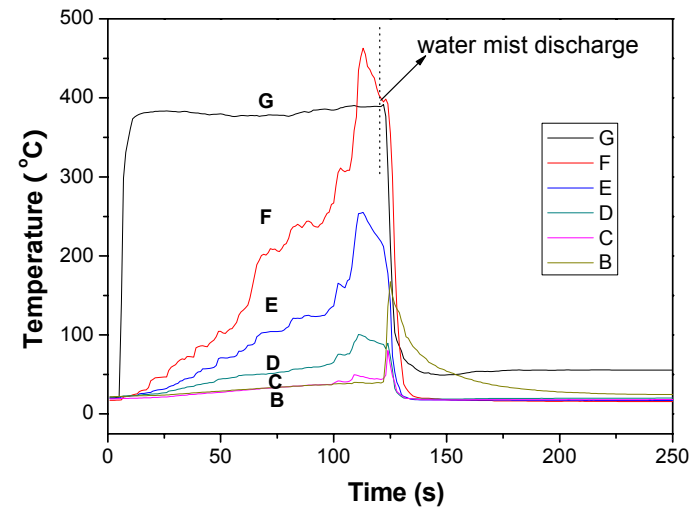

(b) Test SMW-2

Fig. 9. Temperature curves for tests SMW-1 to SMW-4. 


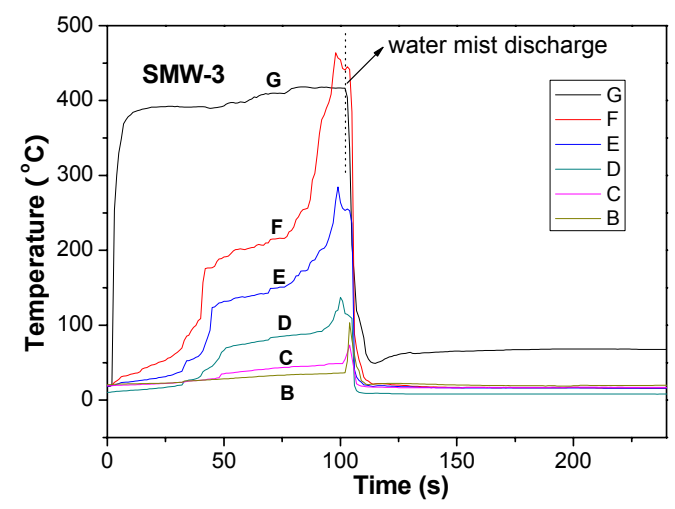

(c) Test SMW-3

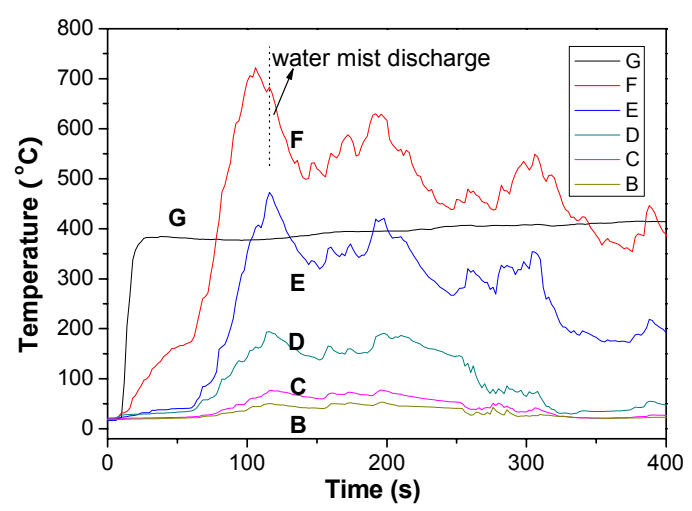

(d) Test SMW-4

Fig. 9. Temperature curves for tests SMW-1 to SMW-4 (Cont'd).

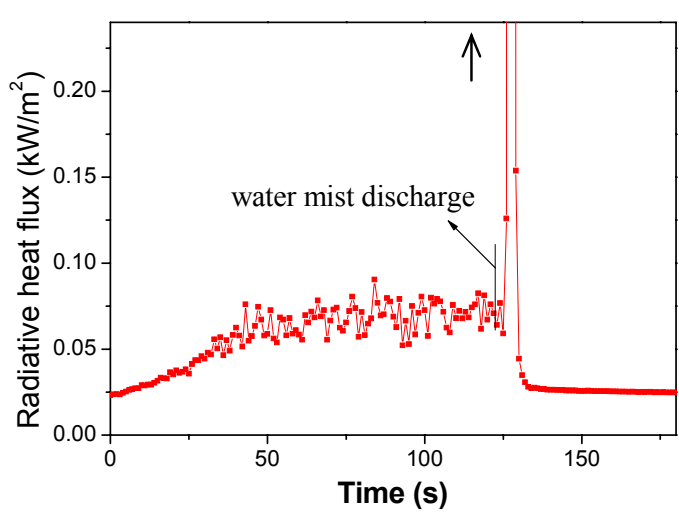

(a) Test SMW-1

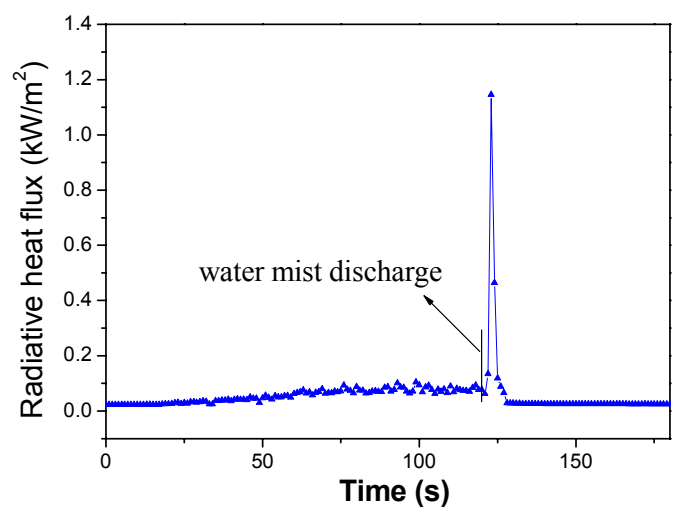

(c) Test SMW-3

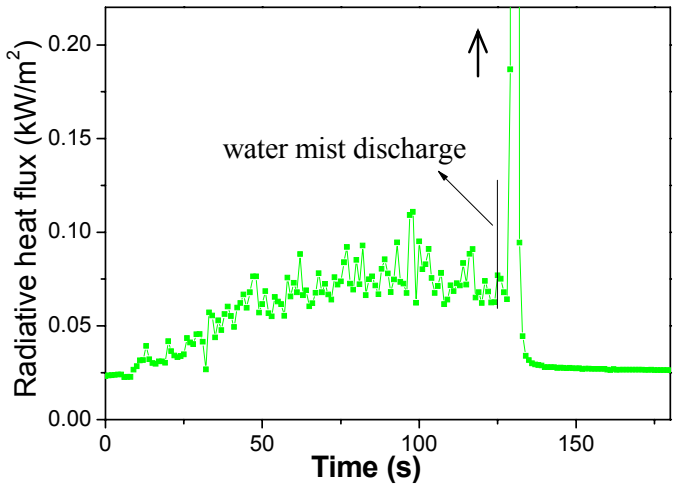

(b) Test SMW-2

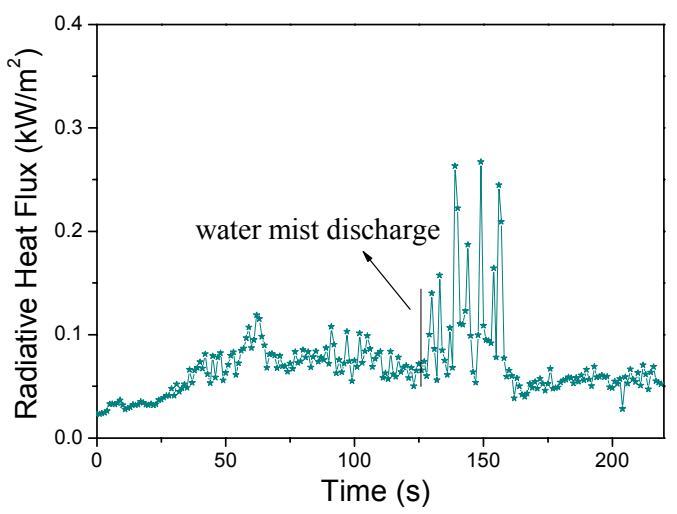

(d) Test SMW-4

Fig. 10. Radiative heat flux for tests SMW-1 to SMW-4. 


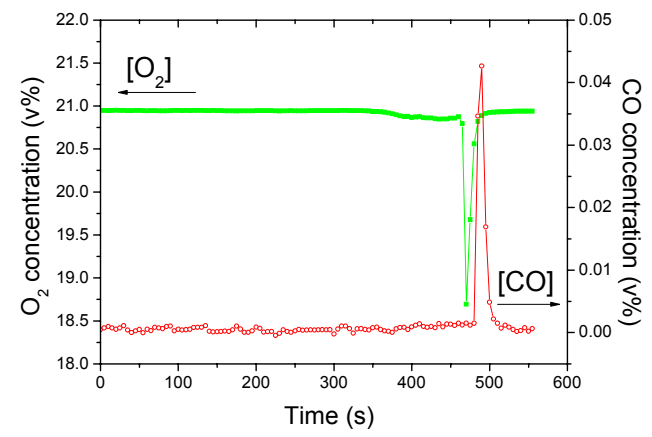

(a) Test SMW-2 $\left[\mathrm{O}_{2}\right]$ and $[\mathrm{CO}]$

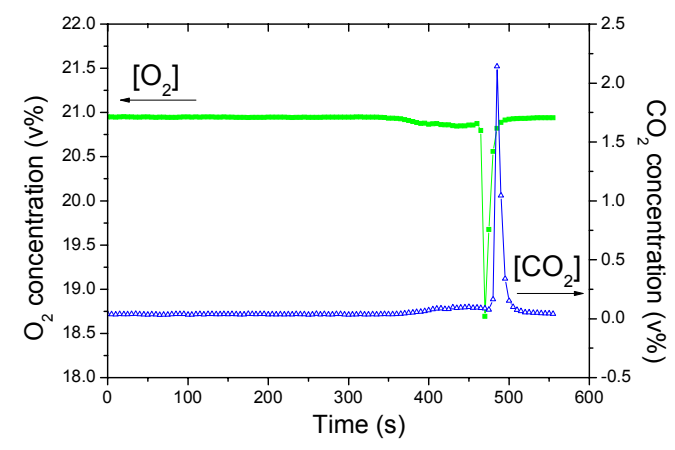

(b) Test SMW-2 $\left[\mathrm{O}_{2}\right]$ and $\left[\mathrm{CO}_{2}\right]$

Fig. 11. Gas concentration curves in test SMW-2

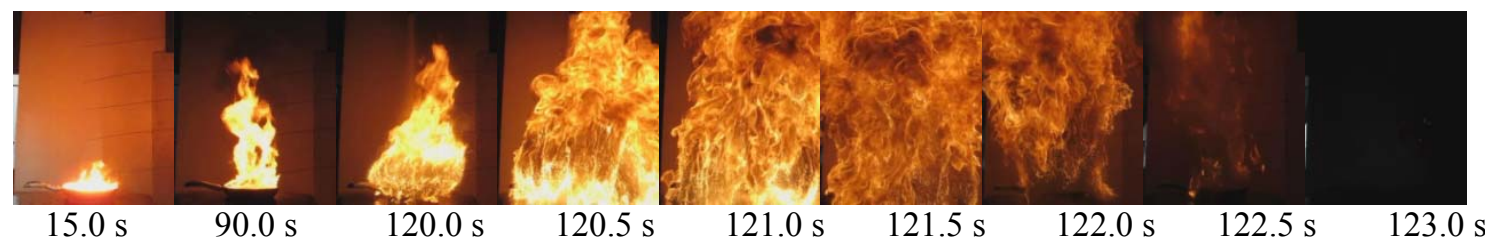

(a) Test SMW-2

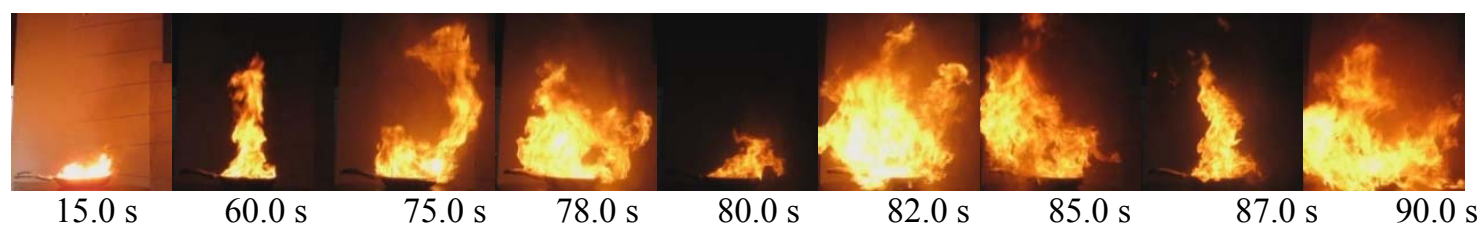

(b) Test SMW-4

Fig. 12. Photographs for test SMW-2 and SMW-4

\section{SUPPRESSION WITH GAS-SOLID DRY POWDERS}

Three suppression tests using dry powder on cooking oil fire, SDP-1, SDP-2 and SDP-3 were carried out, and their summary is shown in Table 3 . The same amount of dry powder was used for all three tests. The nozzle was placed $0.8 \mathrm{~m}$ above the cooking oil pan. After heating the wok for $90 \mathrm{~s}, 500 \mathrm{ml}$ of cooking oil was poured in. Ambient air temperature was $20^{\circ} \mathrm{C}$ and relative humidity valued at $50 \%$.

The heat release rates are shown in Fig. 13, air temperature in Fig. 14 and radiative heat flux in Fig. 15. Gas concentration curves on $\left[\mathrm{O}_{2}\right],\left[\mathrm{CO}_{2}\right]$ and $[\mathrm{CO}]$ are plotted in Fig. 16.

Flame was stronger upon discharging of dry powder in all the three tests, as shown in Fig. 17. But the flame volumes were much smaller than those in SWM tests. In SDP-1 and SDP-2, some oil was spilled and spread under the table. These fires ignited by spilled oils were difficult to be extinguished. The associated fire extinguishing time was relatively longer. In SDP-3, the dry powder showed high efficiency in extinguishing cooking oil fires. Re-ignition did not occur.

It was demonstrated that the discharging pressure is a key factor of the suppression results with dry powders. The burning oil would be splashed out when the discharge pressure became higher, resulting in fire brands and ignition of other combustibles. Proper discharge pressure should be selected according to the height of the nozzle and the physicochemical characteristics of the dry powder particles, so as to put out the fire within the shortest time. 
Table 3. Fire suppression tests with dry powder as suppressant.

\begin{tabular}{|c|c|c|c|c|}
\hline \multicolumn{2}{|l|}{ Test Number } & SDP-1 & SDP-2 & SDP-3 \\
\hline \multicolumn{2}{|c|}{ Discharge pressure $(\mathrm{MPa})$} & 0.6 & 0.4 & 0.1 \\
\hline \multicolumn{2}{|c|}{ Average particle size $(\mu \mathrm{m})$} & 1.8 & 1.8 & 1.8 \\
\hline \multicolumn{2}{|c|}{ Peak HRR before dry powder discharged $(\mathrm{kW})$} & 35.9 & 37.6 & 37.2 \\
\hline \multicolumn{2}{|c|}{ Peak HRR after dry powder discharged $(\mathrm{kW})$} & 101.1 & 45.7 & 47.3 \\
\hline \multicolumn{2}{|c|}{ Peak cooking oil temperature $\left({ }^{\circ} \mathrm{C}\right)$} & 412.4 & 415.8 & 412.0 \\
\hline \multicolumn{2}{|c|}{ Peak flame temperature $\left({ }^{\circ} \mathrm{C}\right)$} & 551.7 & 639.1 & 630.6 \\
\hline \multicolumn{2}{|c|}{ Peak radiative heat flux $\left(\mathrm{kW} / \mathrm{m}^{2}\right)$ before dry powder discharged } & 0.125 & 0.119 & 0.127 \\
\hline \multicolumn{2}{|c|}{ Peak radiative heat flux $\left(\mathrm{kW} / \mathrm{m}^{2}\right)$ after dry powder discharged } & 0.452 & 0.375 & 1.37 \\
\hline \multicolumn{2}{|c|}{ Fire extinguishing time $t_{\mathrm{E}}(\mathrm{s})$} & 10.0 & 26.0 & 1.0 \\
\hline \multicolumn{2}{|c|}{ Amount of dry powders consumed for fire extinguishment $\mathrm{m}_{\mathrm{E}}(\mathrm{g})$} & 65.5 & 98.2 & 20.4 \\
\hline \multirow[t]{2}{*}{$\operatorname{Max}[\mathrm{CO}](\mathrm{v} \%)$} & Before & $2.13 \times 10^{-3}$ & $1.02 \times 10^{-3}$ & $1.47 \times 10^{-3}$ \\
\hline & After & $1.28 \times 10^{-2}$ & $6.39 \times 10^{-3}$ & $3.38 \times 10^{-3}$ \\
\hline \multirow[t]{2}{*}{$\operatorname{Max}\left[\mathrm{CO}_{2}\right](\mathrm{v} \%)$} & Before & $9.92 \times 10^{-2}$ & $1.02 \times 10^{-1}$ & $1.06 \times 10^{-1}$ \\
\hline & After & $2.18 \times 10^{-1}$ & $1.20 \times 10^{-1}$ & $1.21 \times 10^{-1}$ \\
\hline \multirow[t]{2}{*}{$\operatorname{Min}\left[\mathrm{O}_{2}\right](\mathrm{v} \%)$} & Before & 20.8566 & 20.8522 & 20.8533 \\
\hline & After & 20.6871 & 20.8312 & 20.8271 \\
\hline
\end{tabular}

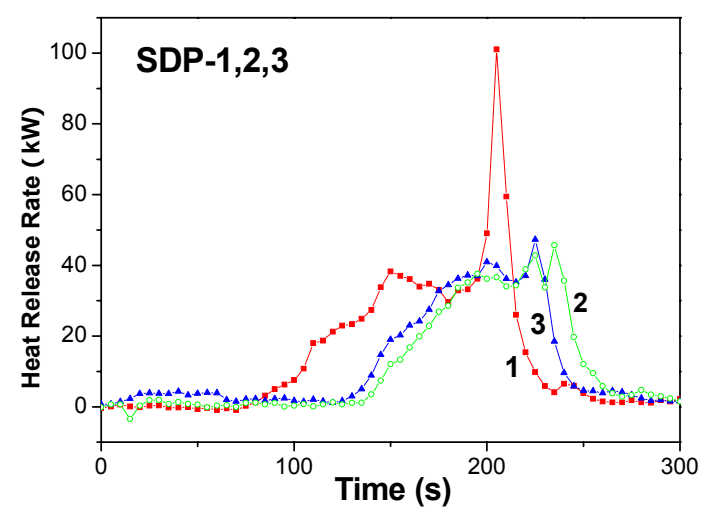

Fig. 13. Heat release rate measured for tests SDP-1 to SDP-3.

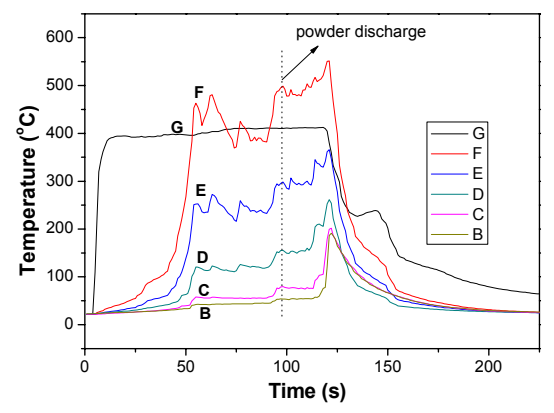

(a) Test SDP-1

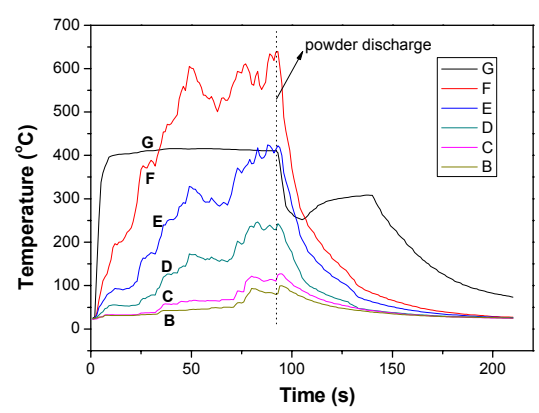

(b) Test SDP-2

Fig. 14. Temperature curves for tests SDP-1 to SDP-3. 


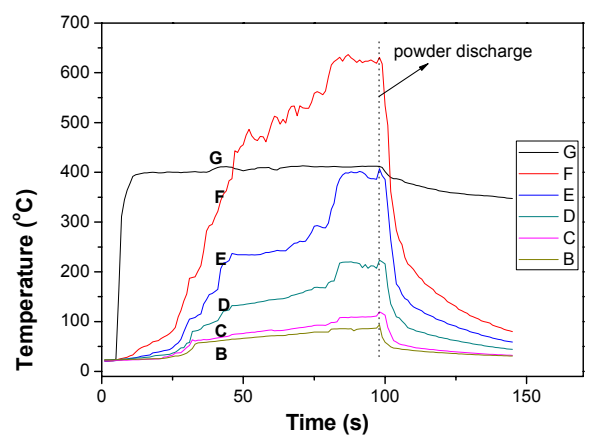

(c) Test SDP-3

Fig. 14. Temperature curves for tests SDP-1 to SDP-3 (Cont'd).

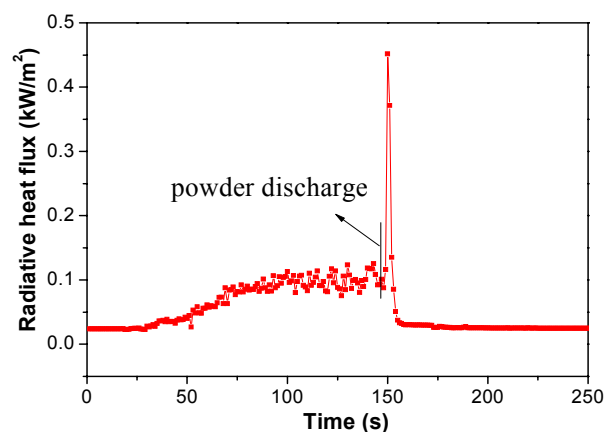

(a) Test SDP-1

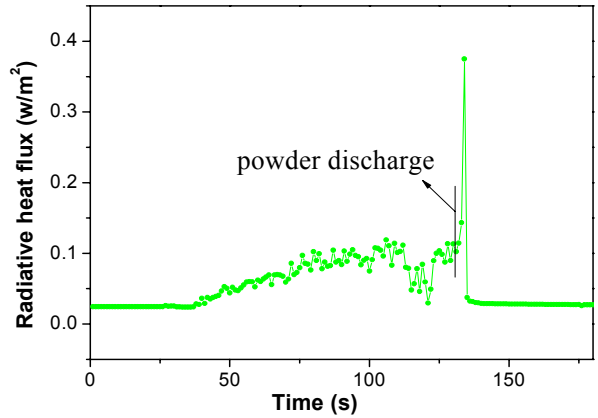

(b) Test SDP-2

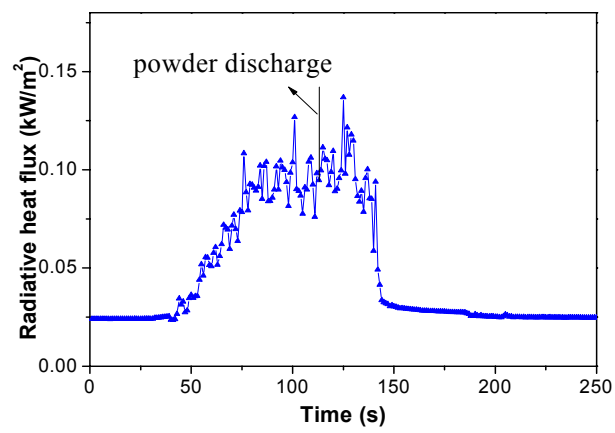

(c) Test SDP-3

Fig. 15. Radiative heat flux for tests SDP-1 to SDP-3. 


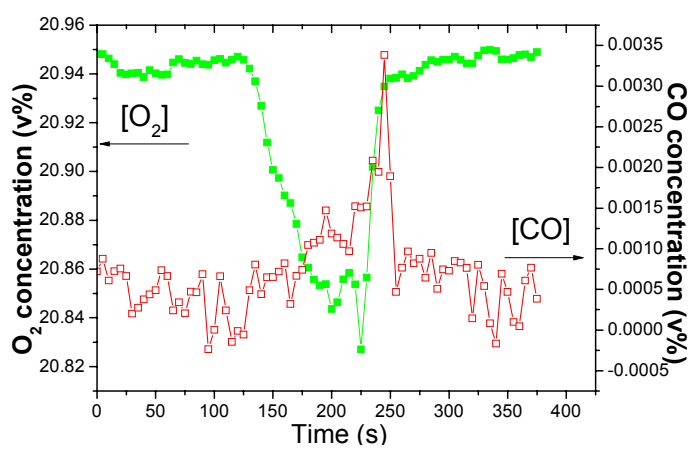

(a) Test SDP-3 $\left[\mathrm{O}_{2}\right]$ and $[\mathrm{CO}]$

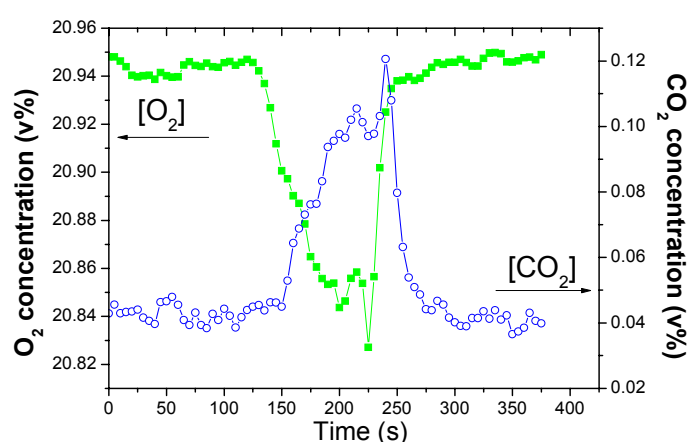

(b) Test SDP-3 $\left[\mathrm{O}_{2}\right]$ and $\left[\mathrm{CO}_{2}\right]$

Fig. 16. Gas concentrations in test SDP-3.

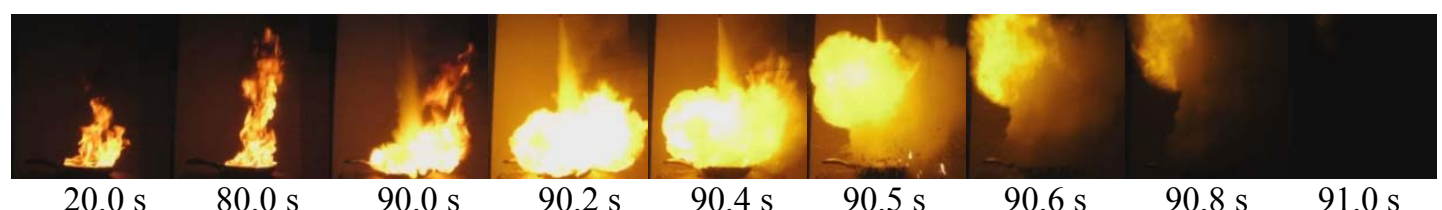

Fig. 17. Photographs for test SDP-3.

\section{CONCLUSION}

The above experimental results provide useful data for fire hazard assessment of cooking oil fires in open kitchen. The performance of water mist and dry powders in suppressing cooking oil fires were also evaluated. The following conclusions can be drawn from this study:

- $\quad$ Fires that were ignited by $500 \mathrm{ml}$ of cooking oil in a $25 \mathrm{~cm}$-diameter pan induced the maximum heat release rate of about $33.2 \mathrm{~kW}$ and radiative heat flux of about $0.114 \mathrm{~kW} / \mathrm{m}^{2}$. The flame temperature could be as high as $675^{\circ} \mathrm{C}$, and the burning could last for about $519 \mathrm{~s}$.

- Water mist can suppress cooking oil fires effectively under appropriate operating pressure. But the flame will grow stronger when the water mist mixes with the flames, resulting in a much larger heat release rate up to $868.1 \mathrm{~kW}$. This might hurt passers-by or ignite combustibles in the kitchen.

- Gas-solid dry powder also showed high efficiency in extinguishing cooking oil fires. Similar to water mist, flame enlargement would occur upon discharging of dry powder to the flames. The peak heat release rate was $101.1 \mathrm{~kW}$, which was lower than that of water mist. The gas-solid composite particles could extinguish the fires within $1 \mathrm{~s}$ without any re-ignition.

- $\quad$ Compared with water mist, dry powder showed higher efficiency with shorter fire extinguishment time, and fewer agents were consumed. The discharge pressure was also much lower. For dry powder, $0.1 \mathrm{MPa}$ of discharge pressure is adequate for fire extinguishment. But water mist with discharge pressure lower than $0.4 \mathrm{MPa}$ could not pass through the flame plume and extinguish the fire.

- $\quad$ Discharge pressure is a key factor of fire suppression. The fire can only be extinguished quickly under appropriate operating pressure. Higher pressure will result in oil spill. Water mist particles discharged at lower pressures might not travel through the flaming region to suppress the fire effectively. To guarantee the best performance, discharge pressure should be set according to the distance between the nozzle and the pan and the properties of water mist particles.

\section{ACKNOWLEDGEMENT}

The work described in this paper was partially supported by a grant from the Research Grants Council of the Hong Kong Special Administrative Region, China for the project "Aspects of open kitchen fires in tall buildings and protection alternatives" with account number B-Q27R; and partially supported by the National Natural Science Foundation of China (Grant No: 51004088). 


\section{REFERENCES}

[1] Chow, W.K., "Several Points to Note in Performance-Based Design for Fire Safety Provisions in Hong Kong”, Plenary Talk, The National Symposium on Fire Safety Science and Engineering, Beijing, China, 14-16 October 2010.

[2] Centaline Property, http://hk.centanet.com/icms/template.aspx?series=1

[3] Chow, W.K., (2005) Building Fire Safety in the Far East, Architectural Science Review, 48(4): 285-294, http://dx.doi.org/10.3763/asre.2005.4836

[4] British Standards Institute, BS 7974 Application of Fire Safety Engineering Principles to the Design of Buildings - Code of Practice, British Standards Institute, UK, 2001.

[5] Chartered Institution of Building Services Engineers (CIBSE), Guide E: Fire Engineering, London, UK, 2010.

[6] Buildings Department, Code of Practice for Fire Safety in Buildings 2011, Hong Kong Special Administrative Region, Draft version released for public consultation in September 2011, Implemented April 2012.

[7] Fire Services Department, Code of Practice for Minimum Fire Service Installations and Equipment and Inspection, Testing and Maintenance of Installations and Equipment, Hong Kong Special Administrative Region, 2012.

[8] Chow, W.K., (1995) Zone Model Simulations of Fires in Chinese Restaurants in Hong Kong, Journal of Fire Sciences, 13(3): 235-253, http://dx.doi.org/10.1177/0734904110385064

[9] Wu, H.H., A Critical Study on the Fire Safety for Big Hotels in Hong Kong, PhD Thesis, Department of Building Services Engineering, The Hong Kong Polytechnic University, Hong Kong, 2006.

[10] Madrzykowski, D., Forney, G.P., and Walton, W.D., Simulation of the Dynamics of a Fire in a Two-Story Duplex - Iowa, December 22, 1999, NISTIR 6854, Building and Fire Research Laboratory, National Institute of Standards and Technology, Gaithersburg, MD, USA, 2002.

[11] Madrzykowski, D., Hamins, A., and Mehta, S., Residential Kitchen Fire Suppression Research Needs: Workshop Proceedings, NIST Special Publication 1066, US Department of Commerce, National Institute of Standards and Technology, Gaithersburg, MD, USA, 2007.

[12] Chow, W.K., (2011) Fire Safety Concern on Open Kitchen in Small Residential Units of Tall Buildings, International Journal on Engineering Performance-Based Fire Codes, 10(3): 58-62.

[13] Wong, A.K.K., Experimental Study of Induction Cooker for Fire Hazard, MSc Dissertation, Department of Building Services Engineering, The Hong Kong Polytechnic University, Hong Kong, 2009.

[14] The Guardian III, Owner's Manual for Installation, Operation and Maintenance. Model G300-A Wet chemical extinguisher unit. G310A-A, 2007.

http://www.vulcanfiresystems.com/getdoc/359c1d07-5caf-4636-8a72-52096402cb72/G3manual.aspx

[15] The Guardian, Owner's Manual for Installation, Operation and Maintenance. Model 1384-A Wet chemical extinguisher unit. NO 71758-S, 2000.

http://www.vulcanfiresystems.com/getdoc/1719fefe-5979-4b17-a9da-b2ef63021706/Guardian-I-

Manual.aspx

[16] Underwriters Laboratories Inc., UL300A Outline of Investigation for Extinguishing System Units for Residential Range Top Cooking Surfaces - Issue 3, Underwriters Laboratories Inc., Northbrook, Illinois, USA, 2006.

[17] Novozhilov, V., (2001) Flashover Control under Fire Suppression Conditions, Fire Safety Journal, 36(7): 641-660, http://dx.doi.org/10.1016/S0379-7112(01)00019-4 
[18] Ni, Xiaomin, Chow, W.K., Li, Quanwei and Tao, Changfa, (2011), Experimental Study of New Gas-Solid Composite Particles in Extinguishing Cooking Oil Fires, Journal of Fire Sciences, 29(2): 152-176, http://dx.doi.org/10.1177/0734904110385064

[19] Wu, H.H., Chow, W.K., Zou, G.W., Dong, H., and Gao, Y., "Performance Evaluation of Fire Services Installation in Kitchens of Big Hotels", Proceedings of the $8^{\text {th }}$ International Symposium on Building and Urban Environmental Engineering (BUEE2006), held at Tokyo Institute of Technology, Tokyo, Japan, 10-13 July 2006, pp. 226-231.

[20] Mowrer, F.W., and Williamson, R.B., (1990) Methods to Characteristic Heat Release Rate Data, Fire Safety Journal, 16(5): 367-387, http://dx.doi.org/10.1016/0379-7112(90)90009-4

[21] Chow, W.K., (2007-2008) Combining Heat Release Rates of Combustibles, Journal of Applied Fire Science, 17(3): 251-260, http://dx.doi.org/10.2190/AF.17.3.b

[22] Koseki H., Natsume Y., and Iwata Y., (2001) Evaluation of the Burning Characteristics of Vegetable Oils in Comparison with Fuel and Lubricating Oils, Journal of Fire Sciences, 19: 31-44, http://dx.doi.org/10.1106/F9XE-5J38-T4F0-JTEB

[23] American Society for Testing and Materials (ASTM) International, ASTM E1354-11b: Standard Test Method for Heat and Visible Smoke Release Rates for Materials and Products Using an Oxygen Consumption Calorimeter, West Conshohocken, Pennsylvania, USA, 2011.

[24] Nuclear Regulatory Commission, Fire Dynamics Tools (FDTs) Quantitative Fire Hazard Analysis Methods for the U.S. Nuclear Regulatory Commission Fire Protection Inspection Program (NUREG-1805, Final Report), Chapter 3-6 Estimating Burning Characteristics of Liquid Pool Fire, 2005, pp. 3-3.

[25] Chow, W.K., and Han, S.S., (2011) Heat Release Rate Calculation in Oxygen Consumption Calorimetry, Applied Thermal Engineering, 31(2-3): 304-310, http://dx.doi.org/10.1016/j.applthermaleng.2010.09.010

[26] Blinov V.I. and Khudiakov G.N., (1957) On Certain Regularities of Diffusion Burning of Liquids, DoH Akad. Nauk. SSSR, 113: 241-244.

[27] Qin, J., Yao B., and Chow, W.K., (2004) Experimental Study of Suppressing Cooking Oil Fire with Water Mist using a Cone Calorimeter, International Journal of Hospitality Management, 23(5): 545-556, http://dx.doi.org/10.1016/j.ijhm.2004.03.001

[28] Chow, W.K. and Wu, H.H., "Measured Heat Release Rate in Chinese kitchen 'Wok' Fires", Poster paper at $10^{\text {th }}$ International IAFSS Symposium, University of Maryland, College Park, Maryland, USA, 19-24 June 2011.

\section{APPENDIX A: UL 300A FIRE CHARACTERIZATION}

\begin{tabular}{|c|c|c|c|c|c|}
\hline $\begin{array}{l}\text { Pan Diam } \\
\text { (in) }\end{array}$ & $\begin{array}{l}\text { Time to } \\
\text { Ignition (min) }\end{array}$ & $\begin{array}{l}\text { HRR max } \\
(\mathrm{KW})\end{array}$ & $\begin{array}{l}\text { Oil } \\
\text { Type }\end{array}$ & $\begin{array}{l}\text { Stove } \\
\text { Type }\end{array}$ & \\
\hline 4" pan & 18 & 70 to 100 & corn & electric & \\
\hline $4^{\prime \prime}$ pan & 18 & 65 & peanut & gas & \\
\hline $\begin{array}{l}10^{\circ} \text { pot } \\
10^{\prime \prime} \text { pot }\end{array}$ & $\begin{array}{r}78 \\
145\end{array}$ & 400 & $\begin{array}{l}\text { corn } \\
\text { peanut }\end{array}$ & $\begin{array}{l}\text { electric } \\
\text { gas }\end{array}$ & \\
\hline $13^{\prime \prime}$ skillet & $>93^{\circ}$ & - & peanut & gas & \\
\hline $13^{\prime \prime}$ skillet & 61 & $>100 *$ & peanut & electric & \\
\hline $13^{\prime \prime}$ skillet & 57 & $>100^{* *}$ & corn & electric & \\
\hline $18 \times 21$ pan & 24 & $>100^{* *}$ & corn & gas & \\
\hline \multicolumn{6}{|c|}{$\begin{array}{l}\text { * Ignition not observed } \\
\text { stopped before } \\
\text { maximum achieved }\end{array}$} \\
\hline
\end{tabular}

